\title{
Innovations in long-term care: The case of old people's homes in Slovenia
}

\author{
JANA MALI* \\ Faculty of Social Work \\ University of Ljubljana \\ Ljubljana, Slovenia
}

\author{
Original scientific paper \\ UDK: 364.65-053.9:616-082 \\ doi: $10.3935 /$ rsp.v26i2.1584 \\ Received: August 2018
}

\begin{abstract}
Institutional care for older people in Slovenia is one of the most developed forms of care for older people. The paper aims to present a specific role of homes in the existing and the future systems of long-term care from the perspective of the implementation of the national strategy of social welfare which highlights the individual treatment of its users, their inclusion in implementing and planning of care, as well as in strengthening their independence. On the basis of the survey research which covered all old people's homes in Slovenia, a series of interviews with social workers and residents and field visits to the selected homes excelling in innovative practice, we aim to show the most evident innovations. Among the most visible ones are social innovations, innovations in social welfare and home innovations. The impetus for the emerging innovations depends on the internal factors of care institutions (orientation of management, changes in the quality of services, personal relations) and external factors (cooperation with local authorities, implementation of the national strategy of social welfare). They also have an impact on the effects of innovations which may be short-term or they may have a direct impact on the quality of life in old people's homes. Identifying innovations proves that old people's homes are actively stepping into the area of long-term care which is expected to regulate their future role.
\end{abstract}

Key words: older people, welfare, institutions, innovations, long-term care.

\section{INTRODUCTION}

Long-term care is a phenomenon that may be described as a response to demographic changes faced by all countries of the world. The rapid aging of the population and the simultaneous decrease in the percentage of the young population in modern industrial societies have radically affected the systems that until recently have been relatively stable. Higher life expectancy, the advance of medicine, the decrease in the share of active population and the increasing number of assistance-dependent persons caused changes in family and intergenerational relations (Flaker et al., 2008; Österle, 2011; Leichsenring et al., 2013; Mali, 2013). The ratio of people offering assistance to people receiving assistance has radically changed. As a consequence, the risk of the failure to provide adequate care and support has increased, while at the

* Jana Mali, Faculty of Social Work / Fakulteta za socialno delo, University of Ljubljana / Univerza v Ljubljani, Topniška ulica 31, 1000 Ljubljana, Slovenia / Ljubljana, Slovenija, jana.mali@fsd.uni-lj.si 
same time the burden shouldered by those who provide care has become heavier (Flaker et al., 2008; Filipovič Hrast et al., 2014; Billings et al., 2013).

In Slovenia, demographic changes are the most frequent reason for the introduction of long-term care. It is estimated that by 2020 the number of people over 65 who will need long-term care will rise from the current 30000 to 40000 , and that the number of people aged 20-65 who will need long-term care will also increase. In spite of a long tradition of efforts for transition to community, the system of care in Slovenia is still outstandingly institutionalised. There are more than 22000 people living in institutions and only 1200 in the interim structures, more than 1000 of them receive fairly intensive service (Flaker et al., 2015). People who have exceeded the threshold of subsidiarity and cannot help themselves with their own resources (personal and social capital) tend to have very little chance of staying in the community in spite of the relatively well-developed community services. The system of financing, the culture of care and the lack of an integrated system of services make community care possible predominantly to those with less intensive needs. In spite of numerous innovations and moving of a larger number of residents into interim structures, the institutional system still prevails (Hlebec and Mali, 2013; Filipovič Hrast et al., 2014; Mali et al., 2017). Personally-tailored intensive services which provide the best response to users' needs are either underdeveloped (i.e. personal assistance, individual care plan and packages of services) or inadequately regulated and not intensive enough (i.e. home care, field work). Also, it is possible to trace a rather too extensive typification in community provision and services (there prevail residential groups and day-care centres) or the lack of variability.

In compliance with the trends in care produced by long-term care, we have re- searched the occurrence of innovative forms of care in old people's homes, the most widespread and developed places for long-term care of the older people in Slovenia. In the world, old people's homes are divided into specialised homes, i.e. nursing homes, shelter housing, housing for people with dementia and independent living facilities; however, in Slovenia, we have general homes that provide care in one place for all the groups of people mentioned above. The trends in the development of care strive to provide individualised care in institutions and expand the community dimension of care, since the majority of old people's homes provide care for older people who still live in the community (The resolution on the national social welfare programme 2013 - 2020, 2013). Old people's homes that provide existing and planned forms of help for older people who still live in their home environment prove that national care is not necessarily solely linked with classic care-provision in institutions with their doors closed to the community. Developing care in the community and going beyond classical institutional care provides for new forms of old people's care to emerge inside and outside particular old people's homes.

Since research on innovative forms of care in old people's homes in Slovenia has not been conducted yet, our research aims at two goals: (1) to present the existing and planned innovative forms of care in old people's homes and (2) to show the implementation of the national strategy of social welfare from the perspective of the individualised treatment of users and their inclusion in the implementation and planning of care in old people's homes as well as from the perspective of their own empowerment and independence (Mali et al., 2017). The purpose of this paper is to present the main conclusions of our research from the perspective of both of the set aims. 


\section{THE RELEVANCE OF INNOVATIONS IN LONG- TERM CARE INSTITUTIONAL SETTINGS}

The resolution on the national social welfare programme 2013 - 2020 (Official Journal of the Republic of Slovenia, 39/2013) highlights the individual treatment of users, the relevance of innovation and permanent introduction of improvements in the programmes and services of social welfare as well as stimulation in view of outcomes that are beneficial to users. The strategy also promotes the relevance of programme and service development and planning, along with the implementation of services and programmes. The definitions of the national strategy are based on the 'critical theory' of institutions and total institutions (its most prominent representative is Goffman, 1961) and the normalisation principles (see Wolfensberger, 1972; Brandon and Brandon, 1992; Flaker, 1998 in Slovenia, in the area of old people's homes developed by Mali, 1998, 2008), which draw attention to everyday perspective on life in an institution. Although critics of institutional care first emerged in the second half of the previous century, criticism is still topical today, since (total) institutions still shape the destiny of many people.

In the area of institutional care for older people, ideas about how to change the institutions are still often triggered by research in many various fields. We can trace the guidelines for deinstitutionalisation (Flaker and Ramon, 2016; Mali, 2016), transformations of medically-oriented care into socially-oriented care (Peace, 1998; Diamond, 2000; Mali, 2011a) and even ideas on the social revolution as a move from providing 'recreation' to providing opportunities for emotional and meaningful social engagement (Theurer et al., 2015: 202). Changes may also be traced under the terms of novelty, social innovation or innovation in the area of social welfare. Since the expression "innovation" has become a mobilising slogan and since we live in a society of constant change, we need to pay attention to the true nature of novelty (Mulgan et al., 2007). Each novelty or innovation does not mean performance of the real change we strive to attain. Some novelties are quite new in the sense of new forms (of organisation, services, etc.); however, they do not produce new content (effects, relations, new quality of life). Even worse, they may aggravate things.

The popularisation of innovation in general or an actual, concrete innovation may produce the feeling of novelty. This is then the case of innovation for the sake of innovation. The motif of the seeming innovation may be a possibility of someone advancing the change, strengthening one's power or influence, but it may, in the case of innovation from top to bottom only mean a seeming adaptation to the demands from the higher authorities, thus creating the appearance of change without any serious intentions to change anything. Seelos and Mair (2017: 5) draw attention to an important point when dealing with innovation: "We assert that innovation per se does not create impact. Innovation generates the potential for impact creation." It may be perilous if the relevance of innovation is always seen only as positive changes in the way a particular organisation functions. Innovations are just a method that may or may not bring us positive changes, therefore it is essential to set criteria for innovations and their implementation.

Brandsen et al. (2016: 6-7) suggest the following definition of social innovation: "Social innovations are those that, created mainly by networks and joint action in social realms beyond business and government routines, at any given moment, raise the hope and expectations of progress towards something "better" (a more socially 
sustainable/ democratic/ effective society)." To a large extent, our orientation follows the cited definition, as we aim to show the areas in which Slovenian old people's homes strive to bring changes for the better in the institutional care of older people, which is a relevant part of long-term care.

\section{RESEARCH METHOD}

The conducted research is descriptive, as we describe the scope (the abundance and variety) as well as types of innovation in old people's homes. The research is also applicative, since innovations in homes are adequately presented and analysed. Partly, the research also involves action-research (Mesec, 2006), which enabled us to encourage reconsideration of innovations, whereas the field approach with visits sparked numerous relevant debates on innovations.

The main research questions pertaining to the observed phenomenon (innovations) were:

1. Which innovations were advanced in old people's homes?

2. What affects the development of innovations?

3. What is the impact of innovations?

As these questions can be perceived in different ways and by different registers that need to provide answers, we used a mix of methodologies that involved quantitative and qualitative data. This included the most contemporary research methodology in social sciences, which involves the complementary combining of qualitative and quantitative methods. This form of research enables a holistic approach to measurement, analysis and interpretation of collected data (Lobe, 2006). Two types of combining research strategies have been put in the foreground: (1) methodological triangulation, which involves the use of qualitative and quantitative methodologies in one research; and (2) data triangulation, which enables the use of various types of collected data using either qualitative or quantitative research methods. We have also used two different qualitative research methods and ensured the comparison between different qualitative empirical data within one qualitative research. The selected research methodology enables holistic research on the subject of a research problem and increases the credibility of results.

According to the course of the study, our research may be divided into two phases. In the first phase, we created a questionnaire for all the old people's homes in Slovenia that enabled us to investigate the presence of both aims of the project in a selected home. The results of the first part of research provided a base for drawing up the study of the second part. In the second phase, we conducted two types of research. The first type was a combination of qualitative and quantitative research. It showed whether or not the residents and the social workers that assist them were enabled to decide autonomously and independently on everyday life in their old people's home, on their influence on the implementation of the institutional care, on their participation in planning their life in a home and thus involving users in providing quality services in a residential home. The second type of research involved case studies of individual old people's homes that were selected on the basis of the results of the survey questionnaire conducted in the first phase of the research. We visited ten old people's homes that exercise innovative forms of institutional care. 
Figure 1

Phases and integral parts of the research

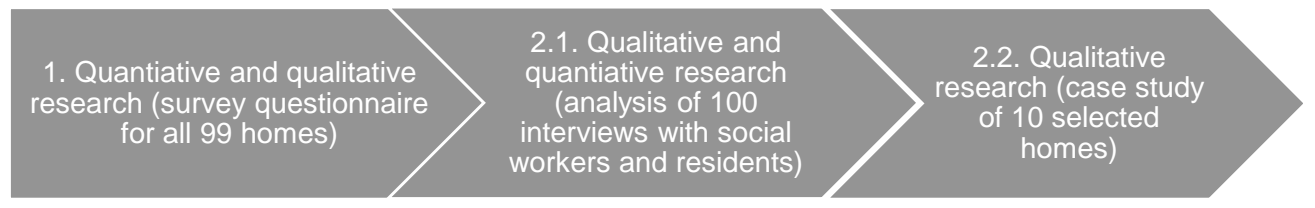

In the first part of the research, we created a questionnaire for all old people's homes in Slovenia, which enabled us to investigate whether a particular home worked innovatively and what the circumstances of such processes are. We ended up creating three separate questionnaires. The first one was intended for the managers, the second one for social workers and the third one for the representatives of the residents' council. Each questionnaire was composed of a combination of closed-ended and open-ended questions: each closed-ended question was followed by an open-ended question in which the respondents could explain a particular phenomenon in their own words, which was then recorded. In this phase, we aimed to get as many detailed data on the research subject as possible.

In the second part of the research (visits to old people's homes and interviews with residents and social workers) we used a partly-standardised questionnaire, composed of a qualitative and quantitative assessment of each of the four research variables: (1) the possibilities that residents had for autonomous and independent decision-making in everyday life at their home; (2) their influence on the carrying out of institutional care; (3) their participation in planning their life in the old people's home and thus (4) how much the users were involved in ensuring the quality of services. The qualitative definition was followed by a descriptive justification of their assessment. The respondents provided their own descriptions, in their own words, of concrete situations from life in their old people's home, their thoughts and opinions regarding their expectations and wishes.

During our visits to the selected old people's homes, we used partly-standardised questionnaires that enabled open conversation on the subject of research. We created guidelines for the interviews with managers, social workers, staff, residents and their relatives. The content involved the following themes: the development of the selected old people's home, individualised care, the impact of residents on their life in their old people's home, monitoring residents' needs, introducing advocacy, self-advocacy and representation, the involvement of users, their relatives and staff in the development of the old people's home, independent decision-making on the scheduling of sleep, free time, awareness of residents regarding their rights during their stay in the old people's home, autonomous choice of room-mates and staff and the permission to form intimate relations.

Since the population is relatively small (less than 100 old people's homes), we did not select a sample home, but rather sent the survey questionnaire to all old people's homes in Slovenia. The survey questionnaire was completed by 56 managers, 74 social workers and 45 residents' representatives. They participated voluntarily, based on our invitation to the study. In the second part of the research (residential care home visits and interviews with residents and social workers) we used a handy sample. The researchers selected homes by accessibility, usually choosing those located close by. They conducted 100 interviews. 
The results of the survey provided us with a solid base to select ten old people's homes with the most visible innovative forms of care. While drawing up a list of selected homes, we considered the following criteria:

1. The managers, social workers and residents' representatives completed the questionnaire. In the first phase, we excluded the residential care homes that had not fully completed the individual questionnaires, as well as old people's homes that did not provide us with completed questionnaires from all the relevant parties, i.e. the manager, the social worker and the residents' representative.

2. The responses to the questionnaire showed that they have indicators for monitoring the quality of care in their home and they make use of those indicators.

3. They presented the changes introduced in care on the basis of their monitoring of the quality of care.

4. They introduce innovations and develop services that go beyond the usual offerings (from the stated 13 criteria, they meet more than half of them). The criteria were: institutional welfare in the second family or in another organised form, shelter housing for older people, temporary care, home-care or social home care, food delivery, help in flat maintenance, medical care, 24-hour connection with personal alarm service, other forms of help, daily home care, daily care in a dislocated unit, cooperation with other similar organisations, associations and individuals that provide various forms of activities for older people outside their residence.

5. In their work they use the following work concepts: monitoring residents' needs, advocacy for residents, enabling self-advocacy for residents, individualised treatment of residents, residents are involved in planning and implementing the care-programme, residents are involved in developing new services and programmes.

6. The following indicators are present in the residential care home, : residents have an active role in implementing care and organising life in the old people's home, residents are involved in planning and carrying out of care-programmes/ services, they are involved in developing new care-programmes/services; residents have an impact on the choice of care programmes/services, individualised care is provided.

The selected sample has a certain purpose and is deliberately biased. However, it is representative for the processes of innovations. It would be pointless to research innovations in places where they are not present. However, one needs to add and draw attention to the fact that we are talking about old people's homes that are more innovative than those that were not chosen for the second phase after their responses to the previous survey didn't match our criteria.

The empirical material has been analysed in two phases. In the first phase, we analysed each research set or component and, in the second phase, we made a synthesis of all sets. The data collected through the initial survey was analysed in two ways. The closed-ended responses were processed only by following the basic, descriptive parameters (the number of responses and their values by percentage), since the explorative and the descriptive nature of the survey, along with the unreliable patterns of the information produced, did not demand a more exigent process. The closed-ended responses were grouped according to their similarity. We processed the interviews conducted with social workers and residents by our researchers in a similar way. Thus, the collected interviews were divided into two groups according to the highest and 
the lowest assessment mark. We were also interested in the content of the responses regarding other data that were not classified into two extreme assessments (the highest and the lowest). The visits to the selected ten homes for older people were each analysed separately. Thus, we gained a good overall, yet elaborated, view of each home and could therefore compare the homes to one another.

After having analysed the data from the first parts of the survey, we proceeded to the collective analysis. We extracted the main findings on the observed variables from the individual parts. While doing so, we used the data from the questionnaires as well as our own free assessments. In order to classify them according to type of vari- able, we used the catalogue of responses to long-term distress by Flaker et al. (2008.).

\section{RESULTS}

More than fifty innovations have been analysed. They differ in scope - they may be social or correspond only to social care or even only to old people's homes. They also differ in the register of responses: innovations may concern general approaches, organisational forms or working methods, i.e. individual services. Some are intended above all for external audiences, others are directed towards changing life in an old people's home. They also differ in prevalence some of them are so prevalent that they are no longer seen as novelties, whereas others are still only just beginning to expand.

Figure 2

The summary of innovations in Home's for older people

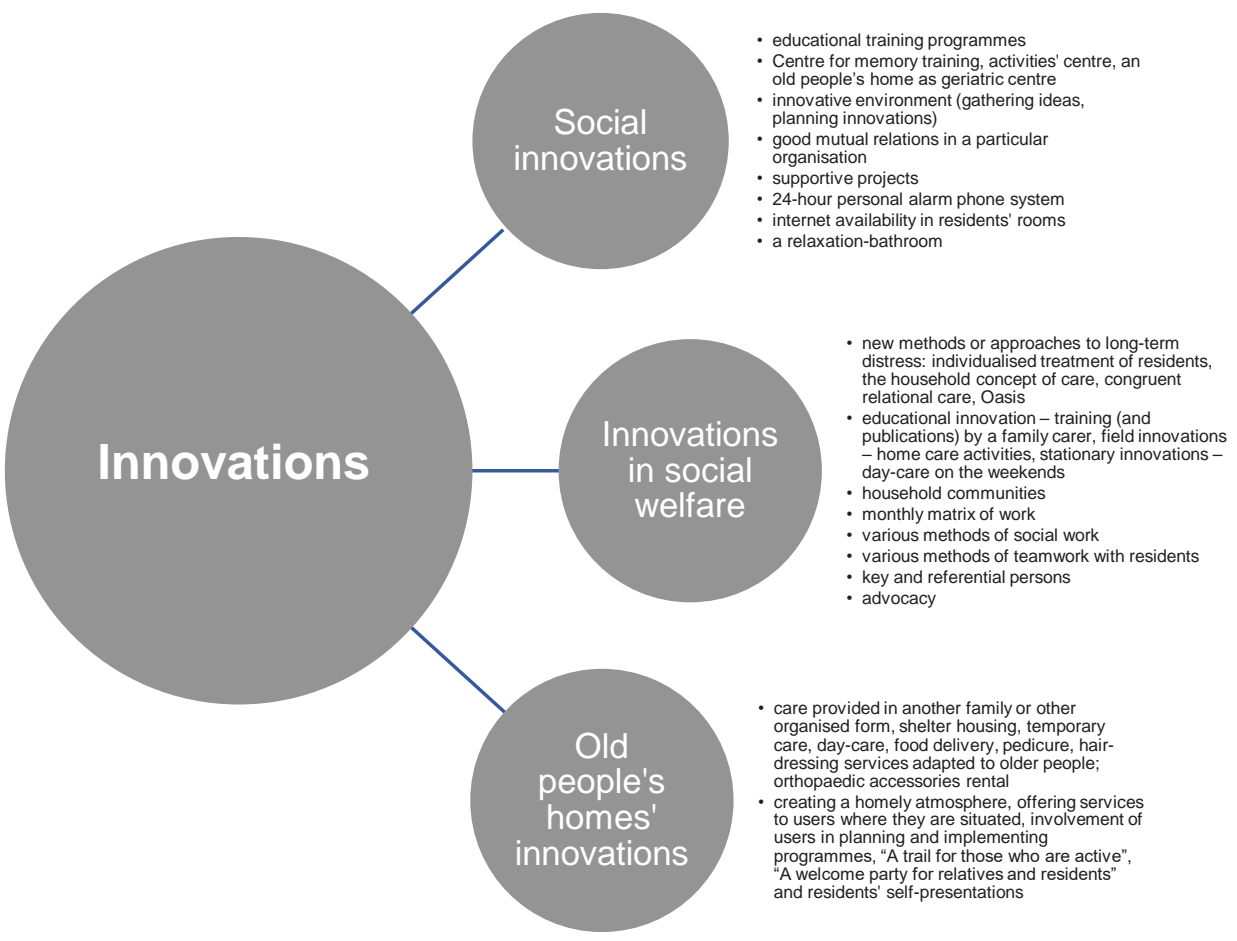




\section{Social innovations}

Almost one third of innovations (17 out of 53) have been marked as social innovations. These include educational institutions intended for the community that can be appointed by old people's homes as knowledge operators, which are of great relevance for the whole community, especially now, in the period of an aging population. They are educational training programmes that help people with the prospect of facing their own death, educational training on dementia intended for broader or specific audiences, offering support for independent living, fall prevention training, pain management or pain-management training.

Forms of help established by old people's homes in cooperation with other agents (e.g. Centre for memory training, activities' centre, an old people's home as geriatric centre) are also included among social innovations. Typical innovations include those which stimulate an innovative environment (gathering ideas, planning innovations) and good mutual relations in a particular organisation (mutual understanding, relations, creative atmosphere and quality residential and working environment).

Social innovations are presented by various supportive projects. For example, encouragement to reveal the knowledge and skills of the residents and staff (Mali et al., 2018). In one of the homes, they introduced various activities in which the residents are put in the role of teachers/instructors: "We encourage residents to pass their knowledge and skills on to other residents. So, we give a course on the German language taught by one of the residents; another resident reads to other residents, predominantly in the unit $A / B$ housing residents with dementia; the residents also prepare and host quizzes on general knowledge; one of the residents occasionally conducts morning exercises on the upper terraceespecially in summer. One of the residents who likes to play golf has prepared an hourlong golf introductory course for residents and staff." (PSD1.3.)

They also often organise activities in which the residents present their hobbies. This is a pleasant novelty in the area of institutional care, as up until now a different sort of culture prevailed in old people's homes. Various skills, knowledge and interests were presented in a kind of talent show to an audience made up of primarily known guests from the local community. However, it is most important for the residents of these types of homes to share knowledge with one another. This is what empowers the community within a home, while, simultaneously, the residents gain positive self-image and respect. A social worker in one of the old people's homes provided a few examples: "A resident who collects old money and coins presented his collection to the other residents. During a cooking workshop, one of the residents showed how she prepares one of her desserts. A resident organised a walk along Salamander's trail, where he walks alone almost every day." (PSD1.3.) This could be interpreted as personal centred help where people comes first, not the institution (Needham, 2013).

The knowledge of the staff gained through their hobbies is also of vital importance. In one of the homes, a resident who takes interest in aromatherapy in her spare-time presented a lecture for the residents and their relatives on the benefits of aromatherapy. The rooms were decorated with aroma lanterns for essential oils, which diffuse enticing aroma. In another old people's home, they encouraged a caregiver from Bosnia and Herzegovina to prepare traditional meals from her country and the residents seemed to welcome them.

Such projects have an impact on the whole community of an old people's home, not only on individuals. The residents and the staff gain a more positive self-image and 
they also empower their community. Other innovations include: fruit and vegetable self-supply, preparation of meals for socially deprived people, baby-sitting during holidays, washing laundry, voluntary work projects, encouraging advocacy.

The social innovations also include a 24-hour personal alarm phone system. Although this is no longer considered an innovation from the technological point of view, it is still an innovation, as it strengthens social contacts among people and provides a feeling of greater personal safety. Other similar innovations include internet availability in residents' rooms, which is no longer an innovation considering the availability of the internet in society, but it is still rarely seen in institutions of social welfare. Among technological innovations, we have included "a relaxation-bathroom," which represents a change in "spatial technology" and technology of personal care, as it introduces a modern concept of bathing, accessories established in a community (seen as something valuable) and introduces the notion that the old people's home is a friendly place (in contrast with the hospital design of old people's homes). A relaxation-bathroom is an additional service in an old people's home and the residents seem to like it. Such bathrooms differ from the usual bathrooms in old people's homes. The equipment and the ambience in these bathrooms offer additional relaxation, because there is relaxing lighting, music and aromas that residents can adapt to their wishes and taste. This project enabled encouragement by relatives for residents to take a bath. Indirectly, it also encourages the involvement of relatives in the care of residents.

\section{Innovations in social welfare}

Almost one third of innovations (15 out of 53) have been marked as innovations in social welfare. Four out of these innovations are innovations at the level of new methods or approaches to long-term distress: individualised treatment of residents, the household concept of care, congruent relational care (developing user-directed quality relations, which are, above all, satisfactory for residents, their relatives and staff) and "Oasis". The latter also involves creating a new environment, but this one introduces a new concept in the way people with greater problems are treated (especially dementia). Oasis is a place intended for residents in the last stage of dementia who need a particular approach to care. In Oasis, special attention is given to touches, basal stimulation and validation. "We received this idea from relatives. It is not only about a different place, but also about a different concept of work, a different approach. We proceed from the resident's life story (what he used to like: people, objects, music, aromas, taking him out in fresh air). The workers take time to study such details. We have found a different way offeeding, not only by using a feeding tube, whereby residents receive food directly into their stomach. This is something that takes time, but it is less painful for residents and less uncomfortable," says a social worker (ŠENTSD4.5.).

Other innovations of this type concern organisation. Among them are:

(1) educational innovation - training (and publications) by a family carer. In one of the old people's homes they have developed their own training programme for a family carer and published the publication A Manual for family carers (Gašparovič, 2007). In the frame of this project, they developed a web page "Family carer" (2018), which provides information on the home care of old people, professional articles, answers to questions about organising help, living environment adaptations, accessories, death and dying. In the era of the information age, this information is most welcome. 
(2) field innovations - home care activities (as a holistic activity, but its individual elements are: cleaning, medical care, other),

(3) stationary innovations - day-care on the weekends.

A relevant innovation in old people's homes is the introduction of household communities that change relations among all those who take part in institutional care and highlight the relevance of the household to create living circumstances that are closer to life outside institutions. The concept of the household introduces the notion of medical care not being the primary activity into institutional care. However, in terms of a basic approach, a different attitude towards residents is perceived. In this, two backgrounds are considered: (1) personally-tailored culture of care and (2) congruent personal care. The outcome is termed "culture of harmonised relations". For this purpose, they replaced the basic "medical" terminology referring to various rooms and work processes in old people's homes with household terms. The wards were renamed as residential units, the nurse's room or ward clinic as the staff room, ward rounds as doctor's visits in rooms, report documentation as delivery book, ward meetings as team meetings, etc. "Our staff no longer wears uniforms. Their occupational clothing is just ordinary clothing (trousers, $T$-shirt, vest andfleece jacket), and the staff have their name and position written on $i t$," explains the manager of one of the old people's homes.

Among innovative activities directly intended for residents, we find that the use of a monthly matrix of work that has been done with the residents is a novelty of innovations in social welfare. A monthly matrix of the work done with residents involves a computer programme that enables keeping tabs on the community and individual work done with residents, thus recording hours of work by the staff with the residents. At first sight, this might be seen as a managerial innovation to provide better organisation of work, but it is also a way of keeping track of residents as well as enabling individualisation of services. In a similar way, one may monitor the work done with residents as a well-established practice in old people's homes. Various methods of social work are used in old people's homes. In some homes, they implement the following-up on of needs to the point of discussing the possibility of moving into the old people's home, i.e. in the phase before being admitted (Mali, 2008). A conversation with future residents and their care-providers is an established way of monitoring needs in that period. But mostly, the follow-up on residents' needs takes place upon admission into an old people's home. For each and every resident, an individual care-plan or programme of care is designed. In some old people's homes, the relatives of the resident are involved. In other homes, an individual care-plan is designed on the basis of the resident's life-story; still in others, a life-story may merely complement part of an individual care-plan. The practice is different from one old people's home to another. In some homes, individual plans are seen as a way of following up on residents' needs, whereas in others, medical-nursing check ups are attributed more attention (Videmšek and Mali, 2018).

As a way of following up on needs, the social workers state various methods of teamwork with residents. Needs are monitored during meetings with residents that may take place regularly, once a month or periodically (with different frequencies), with all residents or with only their representatives (e.g. the food committee). Even self-help groups are seen as a group way of monitoring residents' needs. Social workers also feel that the results of annual surveys contain data that help monitor residents' needs. 
Problems appear when residents and their relatives do not share the same view on residents' needs. The social workers attempt to resolve their conflicts and often take the role of residents' advocates. For this reason, in some old people's homes, they have introduced key and referential persons who advocate for residents' needs (either in relation to relatives or to staff).

Problems also appear when the care-programmes do not respond effectively enough to the residents' needs. According to the respondents, these problems stem from the characteristics of old people's homes as total institutions described by Goffman (1961) (e.g. less privacy, respecting the residents' will and choice, etc.). They attempt to solve problems by consulting the staff and educating them on the relevance of user-oriented implementation of care.

Advocacy was also included in the category of innovations in social welfare, not in terms of a form of innovation, but rather as an innovation in approach and method of work, because it prevails in $70 \%$ of old people's homes in Slovenia but is not particularly organised or defined. Social workers define advocacy as being a part of their professional role in a home, so this is professionalised advocacy. But this interpretation is incorrect. Professional advocacy is exercised by qualified and paid advocates (McDonald, 2010; Mali, 2011b; Urek, 2017), whereas the type of advocacy raised by social workers is advocacy by experts (professionals), i.e. the staff employed in an old people's home. Most often a social worker has the role of an advocate when conflicts arise between relatives and residents, staff and residents, various institutions and residents and, also, when it comes down to balancing the needs of residents and the demands of institutions. They identify the role of an advocate as stated in the Mental Health Act (Official Journal of the Republic of Slovenia, 77/08 in 46/15). The right to access advocacy is given to residents with dementia in secured wards. They also define the role of an advocate as: informing, counselling, empowerment, finding solutions for distress.

According to some respondents, the collective forms of advocacy are: residents' council, residents' meetings and ward residents' meetings. However, these activities show a decreased interest of residents in collective advocacy. The meetings reflect the passivity of residents, a less critical attitude towards life in old people's homes and similar. The respondents suggest that the role of residents as co-creators of life in an old people's home should be strengthened, and this may be achieved through the concept of care that highlights residents' autonomy. However, education is also of great relevance, not only for the staff, but also for the residents. Education could strengthen the awareness of residents regarding their need for advocacy and self-advocacy. In one of the surveyed old people's homes, the establishment of a group for encouraging self-advocacy has been planned.

Contrary to social innovations, the majority of innovations perceived as innovations of social welfare are intended to be used in old people's homes. But external users receive the forms of home care, whereas family care-providers receive training in home care during weekends.

\section{Old people's homes' innovations}

Approximately one third of innovations have been classified as home innovations. These include either activities that are not innovative in general, but go beyond traditional institutional care (care is provided in another family or other organised form, shelter housing, temporary care, day-care, food delivery, pedicure, hair-dressing services adapted to older people; orthopaedic accessories rental) or innovations intended to introduce changes in old people's homes 
(creating a homely atmosphere, offering services to users where they are situated, involvement of users in planning and implementing programmes, "A trail for those who are active", "A welcome party for relatives and residents" and residents' self-presentations). this reason, we asked the respondents of our survey what additional activities they provide besides institutional care.

Most often (61\%), they reported having cooperated with other similar organisations, associations and individuals in order to implement various forms of activities in-

Table 1

Innovations and their implementation / development of services that surpass the standard offerings

\begin{tabular}{|c|c|c|c|c|c|c|c|c|}
\hline & Yes & & No & & n.r.* & & Total & \\
\hline & $\mathrm{N}$ & $\%$ & $\mathrm{~N}$ & $\%$ & $\mathrm{~N}$ & $\%$ & $\mathrm{~N}$ & $\%$ \\
\hline $\begin{array}{l}\text { Introduction of innovations and } \\
\text { implementation/development of services that } \\
\text { surpass the usual offerings }\end{array}$ & 28 & 68.29 & 4 & 9.76 & 9 & 21.95 & 41 & 100 \\
\hline $\begin{array}{l}\text { Institutional care in another family or other } \\
\text { organisational form }\end{array}$ & 1 & 2.44 & 27 & 65.85 & 13 & 31.71 & 41 & 100 \\
\hline Shelter housing & 12 & 29.27 & 16 & 39.02 & 13 & 31.71 & 41 & 100 \\
\hline Temporary care & 18 & 43.9 & 10 & 24.39 & 13 & 31.71 & 41 & 100 \\
\hline Home help or social care at home & 16 & 39.02 & 12 & 29.27 & 13 & 31.71 & 41 & 100 \\
\hline Food delivery & 14 & 34.15 & 8 & 19.51 & 19 & 46.34 & 41 & 100 \\
\hline Help with household maintenance & 9 & 21.95 & 13 & 31.71 & 19 & 46.34 & 41 & 100 \\
\hline Medical care & 4 & 9.76 & 18 & 43.9 & 19 & 46.34 & 41 & 100 \\
\hline 24-hour personal alarm phone system & 1 & 2.44 & 21 & 51.22 & 19 & 46.34 & 41 & 100 \\
\hline $\begin{array}{l}\text { Other forms of help (additional services } \\
\text { besides those mentioned) }\end{array}$ & 5 & 12.2 & 17 & 41.46 & 19 & 46.34 & 41 & 100 \\
\hline Day-care & 17 & 41.46 & 11 & 26.83 & 13 & 31.71 & 41 & 100 \\
\hline Home day-care & 13 & 31.71 & 11 & 26.83 & 17 & 41.46 & 41 & 100 \\
\hline Day-care in a dislocated unit & 4 & 9.76 & 20 & 48.78 & 17 & 41.46 & 41 & 100 \\
\hline $\begin{array}{l}\text { Cooperation with other parties to implement } \\
\text { services }\end{array}$ & 25 & 60.98 & 3 & 7.32 & 13 & 31.71 & 41 & 100 \\
\hline Other & 13 & 31.71 & 15 & 36.59 & 13 & 31.71 & 41 & 100 \\
\hline
\end{tabular}

* n.r.= no response given

We foresaw that institutional care is the basic activity provided by old people's homes. We were informed that numerous old people's homes also provide various services for older people who still live in their home environment and are not yet users of institutional care. Several research studies in the recent years are witness to this phenomenon (see Mali, 2014, Filipovič Hrast et al., 2014, Flaker et al., 2015). For tended for older people outside old people's homes. In terms of the content of activities, they were no different to other responses describing innovations that surpassed the standard offerings. For example, if an old people's home is involved in home care, we found, through other responses, that they also provide food delivery. Responses differing in content referred to other services, for example: growing a garden for self-pro- 
vision of fruit and vegetables, orthopaedic accessory rental, pedicure and hair-dresser's services adapted to older people, preparation and delivery of food for the socially deprived, washing and ironing clothes for parties outside the old people's home and education of citizens in the local community (various lectures and workshops for the locals on dementia, support for independent life, prevention of falls, coping with pain).

Also, temporary care has really expanded, as it is offered by $44 \%$ of all respondents involved in the survey. Day-care is also developed and implemented by $32 \%$ of the respondents in an old people's home, i.e. at the very same location as institutional care is provided and for $10 \%$ of respondents, in a dislocated unit of an old people's home. The total number of day-care centres is quite surprising as it points to a greater need for the development of this activity. Also, social home care is quite developed and is implemented by $39 \%$ of the old people's homes involved in the survey. The same is true for food-delivery (provided by $34 \%$ of old people's homes in the survey) and help with household maintenance (22\% of old people's homes). Medical care was provided by a much smaller number (only 9.76\%) of homes. The largest gap in innovative care involves the implementation of temporary care with another family, which was provided by only one old people's home and the implementation of a 24-hour personal alarm phone system, which was also provided by only one institutional-care provider.

\section{Seeming innovations and real changes}

We need criteria for innovations to enable us to assess if a particular innovation has reached or realised the set goals and whether it really responds to the needs of those for whom it is intended. In the case of social care, the users of the system or, more accurately, the residents of old peo- ple's homes and users of other services of old people's homes.

For this reason, we have decided to set autonomy, involvement and individualisation of services as cardinal criteria. We believe that these criteria are the same criteria for normalisation in everyday life and are indicative for empowerment and increasing of the quality of life on the level of individuals and their personal schemes. However, these criteria are also explicitly stated as goals to be achieved in the national programme. Along with the main criteria, it is also essential to consider other indicators in programme documents as well as those set by contemporary professional guidelines (transfer into a community, intergenerational cooperation, community integration and ordinary, everyday life, as well as striking up good interpersonal relations - criteria for normalisation of good relations and socialising).

In terms of the presence or absence of the mentioned criteria, innovations may be distributed into two groups. The first group are innovations that enable changes in the management of old people's homes, but do not have any meaningful impact on individualised care and do not enable the participation of users in care-planning. Such innovations are only superficial and do not produce long-term results. The changes that they do ensure are short-term and do not have direct effect on raising the quality of residents' lives. The second group of innovations are those that have a direct effect on changes to the quality of residents' lives. They influence changes in relations among people who make up an institution that give the central role to residents, who then co-create life in their old people's home.

Since we see old people's homes as an institution whose functioning strongly depends on the relations among people who make up the institution, we have focused our research on relations between the residents 
and staff. The barriers and incentives to introduce innovations are based on mutual cooperation of the residents and staff, the position of residents in relation to staff and vice versa, as well as the understanding of the roles between both parties in designing life in the institution. At the same time, it is essential to consider the differences in understanding the particular criteria for innovations as they are perceived by the representatives of both parties involved. If the residents are not on the same side regarding the presence of a certain criteria for innovation, whereas the social workers are in agreement, the discrepancy needs to be seen as a barrier in providing the right innovations. On the other hand, if social workers disagree, but the residents do not seem to perceive these disagreements, that is also a barrier.

Some key barriers in providing innovations are differing expectations between the residents and staff regarding the implementation of particular criteria for innovations or understanding the role of the residents and staff when it comes down to their implementation. This concerns the differences in the understanding of life in an old people's home as seen by residents and staff. We have conducted a comprehensive research study on the notion of criteria for innovations from the perspectives of both residents and staff. For staff, it may be concluded that they have a central role in an old people's home in the area of implementing all three criteria, as they are part of their professional mission. Comparing residents' and social workers' opinions is therefore relevant in order to recognise the barriers and incentives in the implementation of innovations that have a real impact on the emergence of changes in old people's homes. Below, the key outcomes of incentives and barriers shall be presented.

The residents' control over their life in an old people's home is defined by autono- my in making choices or decisions regarding the activities taking place in a home, the choice or time of meals, visiting hours, participation in events, room-furnishing, making an appointment at the hair-dresser's and being free to come and go. The level of autonomy for healthy, independent, more capable, confident and mobile or cognitively unimpaired residents is relatively high (Mali et al., 2017). However, autonomy is less available or not available at all for those who are not independently mobile, sick, depending on the care of others, have dementia, or are in cognitive decline. Furthermore, the respondents who were part of this group saw their position as an unchangeable fact, so it is a matter of urgency to encourage changes and improvements through innovations. For those with a greater dependency on others (either due to medical condition, mobile or communicative impairment or dementia), we need to double the effort and introduce the measures for empowerment, opportunities for advocacy and flexibility of house rules. In short, we need to make sure that the residents are not in a worse position because of their impairment.

The possibility of choosing is only a privilege of those residents who are largely independent, healthy, less-impaired and cognitively more capable. Those residents who are completely mobile-impaired only have the choice of individual conversations in their room available to them (Mali et al., 2017). A rich offer of activities and various events are therefore not available to them. Their only choice concerns the fact that they may accept or reject having conversations in their room. For them, the lack of possibility to make choices is therefore further encouragement for innovations.

Understanding decision-making in the relevant perspectives of life in old people's homes more or less comes down to the technical questions on decision-making by people in terms of their everyday routine and activities provided in a home. But they 
refer less to other relevant perspectives of independent decision-making in people's lives, for example: where they wish to live, money-management, subtle questions regarding control over one's body in everyday care, demanding ethical questions regarding the rejection of medication or medical treatment and, above all, what sort of support people need to live and make decisions independently. Due to these perspectives, we see the area of autonomy as a barrier to innovations, since inadequate understanding does not provide autonomy.

A particular challenge to innovative activities is the nursing staff, who are of vital importance for residents. According to social workers, their way of working looks far too much towards the medical model or care-provision, in which the possibility of decision-making by the patient is more a hindrance than an advantage. The differences between the social work staff and medical staff may be seen as a barrier to the introduction of innovations, but we state them here in terms of a challenge rather than a barrier, because, by visiting the ten selected old people's homes with most visible innovations, we have concluded that the staff is aware of various care-guidelines and strives to work together using the same methods.

We have also perceived differences in the concept of the possibility of participation among social workers and residents. In spite of various forms of participation, the residents do not feel that they have any influence on anything, as no one consults them in any way regarding activities. We may distribute them into several sub-groups. The first sub-group are residents who are aware that they are no longer active in the processes of decision-making, either because they do not feel like it (anymore), do not want to make decisions for other reasons or they cannot participate in committees or councils. They rationally assess that they have decreased their chances of exercising influence or the possibility of their opinion being heard. The second sub-group describes people with different experiences of co-decision-making and consultation in their home and does not relate their lack of success with their (non-) involvement in the activities of their old people's home or in other forms of participation (since some of the people in this group use them), but rather, equates it with a system that does not enable them to do so. This is a group of residents who may express their opinion, but it is probably not given enough relevance, since it is not expressed during decision-making.

Respecting residents and contributing to their personal growth shows to what extent the staff is involved in care tailored to individual needs. Residents and social workers report positive experiences, stating that they do their best to respect the residents and see them as worthy of respect.

Providing privacy gives the residents a feeling of safety and homeliness and gives the staff confirmation for treating residents with respect. More privacy is provided by single-bed rooms, although this criteria itself does not provide privacy. The staff still needs to be trained in maintaining a respectful attitude towards privacy. More privacy is provided for residents in living apartments, i.e. those who are more independent can lock their doors and withdraw into privacy. According to social workers and residents, rooms containing several beds and which house residents who depend on the help of staff do not provide privacy, so this area is a particular impetus for policy change in old people's homes.

\section{CONCLUSION}

The innovations in old people's homes presented here may be interpreted to be innovations in the context of long-term care. The majority of innovations identified is characterised by a paradigm shift of care, 
which is reflected in exploring the users' needs and finding the sort of help that efficiently responds to users' needs. We may include innovations in social welfare and those typical of old people's homes in the category of a paradigm shift in long-term care (Flaker et al., 2008; Mali, 2013). We found that these innovations were present in two thirds of old people's homes; therefore, we may reasonably assess that old people's homes already implement changes in care that are characterised by a paradigm shift in long-term care.

The key shift in long-term care concerns the methods of working with people that demand experts to adapt to users by involving them as active co-creators of solutions. The staff who work with the residents need to learn to live with them and support them rather than doing things for them (e.g. in household chores) (Flaker et al., 2008: 428). The innovative character of long-term care provided by old people's homes is also reflected in methods of working with residents and involvement of users in designing care. In this area, we have seen that the stated innovations stem from the methods of working with staff that are designed on the basis of analysing the residents' needs. Through this approach, the residents are directly involved in the development of new forms of care that surpass the classical attitude towards the residents as passive recipients of help.

Long-term care does not see the role of users as passive recipients of help. The focus of care is on a person, not an institution or experts employed in an institution. A human who needs long-term care, i.e. a user, is a partner in the process of care-provision (Lynch, 2014). That means that a user and an expert create a relationship based on equal cooperation in defining and finding solutions for distress (Flaker et al., 2013).

Supposedly, long-term care should provide a sustainable system of help and stim- ulate the development of new forms of care intended for older people. The innovations we have analysed emerge both inside and outside old people's homes. In some cases, changes have emerged in an old people's home, but the incentive for the development of help takes place outside of institutions (e.g. exploring the reasons to go to an old people's home may be a basis for the development of home-care). However, the opposite also happens, i.e. an old people's home provides services for users living outside of such a home, which may be an incentive for home-care innovations (e.g. training on dementia intended for relatives may be an incentive for dementia training for residents of old people's homes). The results of the impacts of such innovations are an excellent prerequisite to develop an old people's home as an institution for holistic care of older people, because they also foresee the reasons for deinstitutionalisation in the Republic of Slovenia (Flaker et al., 2015). Old people's homes will presumably develop into "geriatric centres" that provide holistic care for older people in a particular local environment. Along with institutional care, they will also provide various forms of community care with associated forms of education and training of unqualified informal care-providers to provide care for older people as well as to disburden caregivers.

With various innovative forms of care, old people's homes prove that they are actively stepping into the area of long-term care. Due to the lack of systemic definition of long-term care and the role of old people's homes, the development of old people's homes is at risk if they are forced to submit to the processes dictated by long-term care on a professional level. For this reason, we suggest systematic monitoring of innovations emerging in old people's homes in Slovenia, since this process enables the design of various forms of book-keeping that may have functional, as well as analytical, relevance. The introduction of innovation 
without support of the founder does not provide for long-term results. The current care-providers are faced with numerous barriers that stem from the fact that the introduction of innovations is not system-regulated. For this reason, the implementation of innovations is at risk.

\section{REFERENCES}

Billings, J., Lechsenring, K., \& Wagner, L. (2013). Addressing long-term care as a system - objectives and methods of study. In K. Leichsenring, J. Billings \& H. Nies (Eds.), Long-term care in Europe: Improving policy and practice (pp. 3-18). Basingstoke: Palgrave Macmillan.

Brandsen, T., Cattacin, S., Evers, A., \& Zimmer, A. (Eds.) (2016). Social innovations in the urban context. Cham: Springer Open.

Brandon, D., \& Brandon, A. (1992). Praktični priročnik za osebje v službah za ljudi s posebnimi potrebami. Ljubljana: Visoka šola za socialno delo, Pedagoška fakulteta.

Diamond, T. (2000). Nursing homes as trouble. In J. F. Gubrium \& J. A. Holstein (Eds.), Ageing and Everyday Life (pp. 401-412). Hoboken, NJ: Blackwell Publishers.

"Family carer". (2018). Available from: http://www. druzinski-negovalec.si/.

Flaker, V. (1998). Odpiranje norosti: vzpon in padec totalnih ustanov. Ljubljana: Založba /*cf.

Filipovič Hrast, M., Hlebec, V., Knežević Hočevar, D., Černič Istenič, M., Kavčič, M., Jelenc-Krašovec, S., \& Mali, J. (2014). Oskrba starejših v skupnosti: dejavnosti, akterji in predstave. Ljubljana: Fakulteta za družbene vede.

Flaker, V., Mali J., Kodele, T., Grebenc V., Škerjanc J., \& Urek M. (2008). Dolgotrajna oskrba: očrt potreb in odgovorov nanje. Ljubljana: Fakulteta za socialno delo.

Flaker, V., Mali, J., Rafaelič, A., Ratajc, S., \& Balantič, K. (2013). Osebno načrtovanje in izvajanje storitev. Ljubljana: Fakulteta za socialno delo.

Flaker, V., Rafaelič, A., Bezjak, S., Dimovski, V., Ficko, K., Fojan, D., Grebenc, V., Kastelic, A., Mali, J., Ošlaj, A., Pfeiffer, J., Ramovš, J., Ratajc, S., Suhadolnik, I., Urek, M., \& Žitek, N. (2015). Priprava izhodišč deinstitucionalizacije $v$ Republiki Sloveniji: končno poročilo, verzija 2.2. Ljubljana: Fakulteta za socialno delo.

Flaker, V., \& Ramon, S. (2016). From institutional to community care: Social work of opening spaces and new solidarities (social work and deinstitutionalisation). Dialogue in praxis, 5(1), 42-48. Available at http://dialogueinpraxis.net/index. php?id $=5 \& \mathrm{a}=$ article $\&$ aid $=61$

Gašparovič, M. (2007). Priročnik za družinske negovalce. Ljubljana: Dom starejših občanov Grosuplje.

Goffman, E. (1961). Asylums. New York: Doubleday.

Hlebec, V., \& Mali, J. (2013). Tipologija razvoja institucionalne oskrbe starejših ljudi v Sloveniji. Socialno delo, 52(1), 29-41. https://www.dlib.si/ details/URN:NBN:SI:DOC-CKBD9PRE

Leichsenring, K., Billings, J., \& Nies, H. (Eds.). (2013). Long-term care in Europe: improving policy and practice. Basingstoke: Palgrave Macmillan.

Lobe, B. (2006). Združevanje kvalitativnih in kvantitativnih metod - stara praksa v novi preobleki?. Družboslovne razprave, 22(53), 55-73.

Lynch, R. (2014). Social work practice with older people. A positive person-centred approach. Los Angeles: Sage.

Mali, J. (1998). Institucionalni vidiki življenja v domovih za stare ljudi. Socialno delo, 37(2), 131-137.

Mali, J. (2008). Od hiralnic do domov za stare ljudi. Ljubljana: Fakulteta za socialno delo.

Mali, J. (2011a). An example of qualitative research in social work with older people: the history of social work in old people's homes in Slovenia. Collegium antropologicum, 35(3), 657-664. https://hrcak.srce.hr/72152

Mali, J. (2011b). Uvajanje zagovorništva starejših oseb. In M. Tratnik-Volasko (ur.), Zagovorništvo starejših (str. 15-27).). Ljubljana: Državni svet Republike Slovenije.

Mali, J. (2013). Dolgotrajna oskrba v Mestni občini Ljubljana. Ljubljana: Fakulteta za socialno delo.

Mali, J. (2014). Social work in residential care facilities for older people as a protagonist of changes in community care for older people in Slovenia. In E. N. Arnold (Ed.), Social work practices: Global perspectives, challenges and educational implications (pp. 233-151). New York: Nova Science Publishers.

Mali, J. (2016). Old age - the Prime and neglect of social work. Dialogue in praxis, 5(1), 62-67. http:// dialogueinpraxis.net/index.php?id=5\&a=article\&aid $=64$

Mali, J., Flaker, V., Perišič, M., L., Rafaelič, A., Rode, N., Urek, M., \& Žitek, N. (2017). Inovativne oblike oskrbe $v$ domovih starejših občanov. 
Končno poročilo raziskave. Ljubljana: Fakulteta za socialno delo.

Mali, J., Flaker, V., Urek, M., \& Rafaelič, A. (2018). Inovacije $v$ dolgotrajni oskrbi: primer domov za stare ljudi. Ljubljana: Fakulteta za socialno delo.

McDonald, A. (2010). Social work with older people. Cambridge: Polity Press.

Mental Health Act. Official Journal of the Republic of Slovenia, 77/2008, 46/2015.

Mesec, B. (2006). Action research. In V. Flaker \& T. Schmid (Eds.), Von der Idee zur Forschungsarbeit: Forschen in Sozialarbeit und Sozialwissenschaft (pp. 191-222). Wien: Böhlau Verlag.

Mulgan, G., Tucker, S., Ali, R., \& Sanders, B. (2007). Social innovation: What it is, why it matters and how it can be accelerated. Oxford: University of Oxford.

Needham, C. (2013). Personalisation: from day centres to community hubs?. Critical Social Policy, 34(1), 90-108. https://doi. org/10.1177/0261018313483492

Österle, A. (Ed.). (2011). Long-term care in Central and South Eastern Europe. Frankfurt am Main: P. Lang.
Peace, S. M. (1998). Caring in place. In A. Brechin, J. W. Walmsley, J. Katz \& S. M. Peace (Eds.), Care Matters (pp. 107-125). London: Sage.

The resolution on the national social welfare programme 2013-2020. Official Journal of the Republic of Slovenia, 39/2013.

Seelos, C., \& Mair, J. (2017). Social innovation and scaling for impact. How effective social enterprises do it. Stanford: Stanford Business Books.

Theurer, K., Mortenson, W. B., Stone, R., Suto, M., Timonen, V., \& Rozanova, R. (2015). The need for a social revolution in residential care. Journal of Aging Studies, 35, 201-210. https://doi. org/10.1016/j.jaging.2015.08.011

Urek, M. (2017). Unheard voices: Researching participation in social work. European journal of social work: the forum for the social professions, 20(6), 823-833. https://doi.org/10.1080/1369145 7.2016 .1278525

Videmšek, P., \& Mali, J. (2018). Od načrta skrbi in programa oskrbe do osebnega načrtovanja in izvajanja storitev. Socialno delo, 57(1), 27-42. https://www. dlib.si/details/URN:NBN:SI:doc-JTGYXKS7

Wolfensberger, W. (1972). The principle of normalization in human services. Toronto, ON: National Institute on Mental Retardation. 
Sažetak

\title{
INOVACIJE U DUGOROČNOJ SKRBI: SLUČAJ DOMOVA ZA STARIJE OSOBE U SLOVENIJI
}

\author{
Jana Mali \\ Fakultet za socijalni rad, Sveučilište u Ljubljani \\ Ljubljana, Slovenija
}

Institucionalna skrb za starije osobe u Sloveniji jedan je od najrazvijenijih oblika skrbi za starije osobe. U radu se nastoji predstaviti specifičnu ulogu domova za starije osobe u postojećem i budućem sustavu dugoročne skrbi iz perspektive primjene nacionalne strategije socijalne skrbi koja naglašava individualni tretman korisnika, njihovo uključivanje u primjenu i planiranje skrbi, kao i jačanje njihove neovisnosti. Na temelju istraživanja koje je obuhvatilo sve domove za starije u Sloveniji, niza razgovora sa socijalnim radnicima $i$ stanarima domova te posjeta odabranim domovima koji se ističu u inovativnim praksama nastojimo pokazati najevidentnije inovacije. Među najvidljivijima su socijalne inovacije, inovacije u socijalnoj skrbi i inovacije domova. Poticaj za nove inovacije ovisi o unutarnjim čimbenicima institucija za pružanje skrbi (orijentacija uprave, promjene u kvaliteti usluga, osobni odnosi) i o vanjskim čimbenicima (suradnja s tijelima mjesne uprave, primjena nacionalne strategije socijalne skrbi). Oni isto tako utječu na učinke inovacija koje mogu biti kratkoročne ili mogu imati izravan učinak na kvalitetu života u domovima za starije osobe. Identifikacija inovacija dokazuje da domovi za starije osobe aktivno ulaze u područje dugoročne skrbi od kojeg se očekuje regulacija njihove buduće uloge.

Ključne riječi: starije osobe, skrb, institucije, inovacije, dugoročna skrb. 